\title{
URBAN HIERARCHY IN SERBIA
}

\author{
Bojan Đerčan, Milica Radaković, Miloš Ostojić, \\ Maja Mirković, Smiljka Obrenov, Jan Vozar' \\ Received: January 102017 | Accepted: June 21, 2017
}

\begin{abstract}
Despite numerous urban studies that analyzed various aspects of Serbia's urban network, little attention was paid to examining the phenomenon of urban hierarchy and urban primacy. Therefore, the aim of this paper is to examine the nature, level and progression of the urban hierarchy in Serbia, as well as its causes and consequences. In achieving these goals, the paper begins with a review of urbanization in Serbia and the methods of its measurement, followed by a discussion of the results obtained. This paper uses data from the Statistical Office of the Republic of Serbia on the number of inhabitants and active population employed in the tertiary-quaternary sector in the period between 1971 and 2011. This paper tested the Rank-size rule, known also as Zipf's law, Urban Primacy Index, and Schmook and Rochefort methods to display the results. This paper concluded that urban primacy is an obvious phenomenon in Serbia. There is a clear distinction between the polycentric urbanized Vojvodina, a somewhat less urbanized central Serbia, and a large range in Belgrade's functional capacity.
\end{abstract}

Keywords: Serbia, urbanization, centrality, hierarchy, cities

\section{INTRODUCTION}

The effectiveness of the urban system in any country largely depends on the distribution in the size and distance of urban centres. This determines whether the urbanization process is the same throughout the region or is centralized (Nicholson, 2003). The urbanization pattern in Serbia was mainly oriented to larger cities.

The Republic of Serbia is going through intensive processes of depopulation and demographic aging, with pronounced regional disproportions of the population. Intensive migrations have resulted in the concentration of the population in all major urban areas and the depopulation of large areas of the Republic of Serbia.

The pronounced regional unevenness between underdeveloped, bigger part of the area and developed territorial areas and segments of the Republic of Serbia is a result of the joint influence of numerous factors and their causal relations (Vujnić, 2014).

University of Novi Sad, Faculty of Scinces, Department of Geography, Tourism and Hotel Management, 3 Trg Dositeja Obradovića, 21000 Novi Sad, contact: dgt.milica.radakovic@student.pmf.uns.ac.rs 
A wide spectrum of inherited cultural, historical, demographic, economic, infrastructural, social and political parameters, respecting the natural and geostrategic position of certain areas, have decisively influenced on the uneven regional development of our country. The consequences on the territory of the Republic of Serbia are evident - huge intraregional and interregional disparities impede development and encourage migration flows. The large and strategically important areas of the Republic of Serbia have remained uncovered in population terms, and their resources are unused. At the same time, there is an excessive concentration of population and economy in more developed centres, which in some way produced negative consequences in the economic, social, spatial and environmental spheres of the same (Aničić, Laketa, Vukotić, 2011).

At first glance, it can be said that the urban network of Serbia is characterized by a favourable distribution of urban settlements, but a little more detailed analysis of the concentration of population and functions show certain problems in them. About $26 \%$ of urban population of Serbia without Kosmet live in Belgrade. Its dominance is indicated by the index of urban primacy with value of 6.3 (the ratio of the population of Belgrade and Novi Sad). The discrepancy between the population of the leading and other urban settlements indicates that Serbia does not have a properly and evenly developed urban system, that is, that the flows of urbanization were not timely directed.

In Serbia, many forms of more and less urbanized areas and several forms of regional urban systems have been identified, and their spatial and functional organization has been established. However, Serbia is insufficiently urbanized, and in terms of the continuity of lasting and spatial forms of manifestation of urbanization, there is a clear distinction between polycentrically urbanized Vojvodina, somewhat less urbanized central Serbia, with an irregular hierarchical structure in urban settlement systems and a large range between the functional capacity of Belgrade and other centres and the low-urbanized area of Kosovo and Metohija (Ćurčić, 1992).

Although a large number of authors dealing with urban processes and urban structures, through their works advocated for the polycentric and balanced development of the network of urban settlements, this concept has not been realized in the practice of regional planning and regional development. It was only during the development of the Spatial Plan of the Republic that an exact analysis of all elements and factors of regional development was carried out, which was used as a base for the strategy whose implementation will carry out demetropolisation of Belgrade agglomeration and mitigate the dysfunctionality in the system of settlements and start functional balancing.

\section{REVIEW OF URBANIZATION IN SERBIA}

The main settlements in Serbia are mainly of Roman and Byzantine origin, and some settlements have even older foundations from prehistoric times. The oldest settlements in this area originate from the Mesolithic, and famous cultures are Lepenski Vir, Starčevo and Vinča. The towns that appear during the Roman Empire are: Sirmium (Sremska Mitrovica), Singidunum (Belgrade), Naisus (Niš), Viminacium (Kostolac), Horeum Margi (Ćuprija), Ulpiana (Gračanica), Kapedunum (Užice), Remeziana (Bela 
Palanka), Iustiniana Prima near Lebane) and others. During the wars, many theretofore major towns lost their importance, or completely disappeared, renewing on the first occasion.

At the beginning of the Middle Ages and in the Ottoman period, those towns that had the most favorable geographical position were held. Such were Belgrade, Niš, Smederevo, Kruševac, Priština. The favourable conditions were along the major rivers (Danube, Sava, Tisa, Morava), accompanied by the main roads of that time. A significant part of today's cities is based on the foundations of cities that are mentioned in medieval chapters and sources. Some of them are Belgrade, Šabac, Valjevo, Smederevo, Užice, Jagodina, Niš, Čačak, Kruševac, Priština. During the Habsburg-Ottoman wars, the cities of Serbia were repeatedly subjected to Habsburg and Ottoman rules. Primacy was taken by towns at borders as places where trade developed. If the environment was economically viable and if the town was established at the intersection of important roads, it often became commercially strong in a short period of time (Obrenovac, Mladenovac).

Urban population was small. In 1834, this number was only 41,347 inhabitants and slowly grew. In 1874 , Belgrade had only 27,605 inhabitants. There was an important ethnic and religious distinction between rural and the urban population. In 1834, the density of population in the Principality of Serbia amounted to $18 \mathrm{inh} . / \mathrm{km} 2$, and in 1874 it was $36 \mathrm{inh} . / \mathrm{km}^{2}$. Due to high natural growth and immigration, the density of population is increasing to $56 \mathrm{inh} . / \mathrm{km}^{2}$. In 1880 in Vojvodina, the population density was 53 inh./ $\mathrm{km}^{2}$, and in 1910, $68 \mathrm{inh} / \mathrm{km}^{2}$. Between the two world wars it was increased from 5linh. / km2 in 1921 to $72.5 \mathrm{inh} . / \mathrm{km}^{2}$ in 1940. During the Second World War, some Vojvodina cities lost large numbers of inhabitants (Vršac, Senta and Sremska Mitrovica), due to occupation terror, persecution of Jews (Senta, Novi Sad) and emigration of Germans (Vršac) (Bubalo-Živković, 2016).

The development of settlement during the 19th century and in the first half of the 20th century shows characteristics typical for the agrarian environment of a very low degree of urbanization and high agrarian overpopulation. Migration is a process that has caused the greatest differences in the demographic development of rural and urban areas. Village-city migration disrupted the existing balance and relative independence of demographic development, creating on the one hand depopulation and discharge of rural areas, and on the other hand an increased number of inhabitants in urban areas. The increase in urban population was also due to natural increase, but also to the change in the status of certain settlements. According to the population census in 1953, about one-fifth of the total population lived in urban settlements (22.5\%), and about two-thirds of the active population (67\%) were agricultural. Vojvodina was most urbanized with $29.5 \%$ of the urban population, then central Serbia with $21.2 \%$ and at the end was Kosovo and Metohija with only 14.6\%. In the period 1961-1971, the urban population growth rate was $4.2 \%$, and the degree of urbanization rose to $40.6 \%$ (central Serbia 40.8\%, Vojvodina 48.8\%, Kosovo and Metohija 26.9\%). Between 1971 and 1981, the growth rate dropped to $2.4 \%$, and the share of the urban population in the total increased to $46.6 \%$ (central Serbia $47.8 \%$, Vojvodina $54.1 \%$, Kosovo and Metohija $32.5 \%$ ). In the period 1981-1991, the growth rate was lower - 1.4\%, while the degree of urbanization increased to 50.7\% (central Serbia 53.5\%, Vojvodina 55.7\%, Kosovo and Metohi- 
ja $37.5 \%)$. During this time the urban population increased by 91,386 inhabitants, while the population of other settlements decreased by 161,000 inhabitants.

The spatial and social mobility of the population from rural to urban settlements and from primary to secondary and tertiary sectors of economy affected the succession of the phases of urbanization, which was manifesting territorially and temporally through demographic, functional and physiognomic changes in both urban and rural settlements.

Complex urban systems are composed of several settlements whose links are the result of the interaction of their structural elements and the different degree of hierarchy. They have the character of the functionally urban or, metropolitan regions. They are distinguished by the high degree of urbanization and the large share of the urban population in the total, high employment of labour in non-agricultural activities, diversified functions and stable daily migration of the workforce. The most important representatives of this type of urban systems are Novi Sad, Niš, Kragujevac and Subotica (BubaloŽivković, 2016).

The Belgrade agglomeration is a complex and dynamic system of urban settlements with a high level of functional and morphological connection with a clearly expressed multilayered hierarchy and a great gravitational influence that goes beyond the state borders. Belgrade is a potential centre of Southeast Europe of first-rate international importance, that is, the centre of the future Euro-Metropolitan region. According to the 2002 Census, the city of Belgrade had a population of 1,574,050, of which 1,280,639 inhabitants lived in urban settlements, or $82.3 \%$. According to the latest 2011 census, there were $1,659,440$ inhabitants in the Belgrade region, of which $1,334,844$ or $81 \%$ made urban population.

As a large agglomeration core of Vojvodina, Novi Sad is a significant part of the conurbation that is expanding towards Belgrade. It is a city that has a significant increase in the number of inhabitants in the last decades, mainly due to migration processes. In 2002, it had 299.294 inhabitants, and in 2011, 377.522 inhabitants.

The city of Niš has 260,237 inhabitants, of which 187,544 inhabitants live in urban settlements (Niš and Niška Banja). If someone applied the socio-geographical method in determining the boundaries of Niš's agglomeration, it would be found that Niš is the centre of a polycentric metropolitan region with over 350,000 inhabitants and a large zone of influence (Bubalo-Živković, 2016).

\section{METHODOLOGY}

The subject of the research is the settlements of Serbia which since February 2016 have had the status of the city. The aim of the research is to determine the urban hierarchy and to get a complete picture of the urbanization of Serbia using the census data, starting from 1971, concluding with the last census conducted in 2011. The task of the research is to analyze the population numbers for each city individually through the aforementioned censuses, to draw conclusions about the fluctuations of numbers, bearing in mind historical events and economic, sociological and other causes. 
Statistical, cartographic, mathematical, demographic and comparative methods were used for data processing. In ArcMap 10.1., the map of Serbia was digitized in order to graphically display the results.

The rank size rule was first noticed by the German geographer Auerbach at the beginning of the twentieth century. The rule refers to the existence of dependence between the size and the number of cities, that is, the tendency of creating the regular rank of the size of cities in the space. These observations were elaborated later by many authors: Zipf, Stuart, Singer, Berry. These interdependencies were theoretically formulated as the Rank size rule (Berry, Garrison, 1959, Soo, 2002). According to this parameter, it can be expected that one city in a set of cities of a country or region, ranked by size, will have as many inhabitants as the largest city, divided by the city's rank in a set of cities. Therefore, the second settlement in a set will have half the population of the largest one, the third will have one third less than the largest, etc. The rank-size rule for the number of inhabitants by cities known also as the Ziph's law is determined by the equation:

$$
S_{n}=\frac{S_{1}}{r}
$$

where $S_{n}$ - is the expected number of inhabitants of the city in the hierarchy, $S_{1}$ - the number of inhabitants of the largest city, and $r$ - the city's rank in a set. Distribution of settlements is most often represented by a graph with an arithmetic scale on which the function has the shape of a curve. Based on Pearson's correlation coefficient, the degree of matching of distribution of the settlements can be determined.

The American geographer Jefferson (1939) noted that in some countries, a capital city - a primate city is the largest and the other cities are considerably smaller, and this phenomenon was called the Law of the primate city. Many scientists believe that this is due to political and economic opportunities, and the exceptional political, economic and social significance of the capital (Mutlu, 1989; Murray, 2003; Sarkar, Maya, 2013; Yousuf, Shah, 2014). The law of the primate city is calculated on the basis of the index of urban primacy:

$$
I=\frac{G_{1}}{G_{2}}
$$

where $I$ - is the index of urban primacy, $G_{1}$ - is the number of inhabitants of the largest city and $G_{2}$ is the number of inhabitants of the second largest city. In practice, the three largest cities are most often used for calculation:

$$
I=\frac{G_{1}}{G_{2}+G_{3}+G_{4}}
$$

Urban primacy is high if the index value is greater than 2. One of the research procedures for determining the degree of development, position and significance of settlements in the network is the Schmook's method for the centrality of settlements (Schmook, 1968). It calculates the centrality as the ratio of the number of active population employed in the tertiary-quaternary sector in the total active population of the region. The centrality is calculated according to the form: 


$$
C_{1}=A_{n} \cdot \frac{T Q_{n}}{A_{n}}-\frac{T Q_{r}}{A_{r}}
$$

where $A_{n}$ - is an active population in the settlement, $T Q_{n}$ - active population employed in the tertiary-quaternary sector in the settlement, $T Q_{r}$-active population in the tertiary - quaternary sector in the region and $A_{r}$ - active population in the region.

The Rochefort's method gives the possibility to graphically display the centrality of the settlement using the equation (Rochefort, 1957):

$$
X=\frac{T Q_{n}}{A_{r}}, \frac{T Q_{n}}{T Q_{r}}
$$

Designations in the form have the same meaning as in the Schmook's model, and X and $\mathrm{Y}$ are abscissa and ordinate of the coordinate system.

According to the population censuses in 1953, 1961 and 1971 there was a division of settlements based on demographic and statistical criteria in relation to the number of inhabitants and the percentage of the non-agricultural population of the settlement. These censuses included a division into urban, mixed and rural settlements. Urban settlements could have at least 2,000 inhabitants, and only if they had over $90 \%$ of the nonagricultural population.

Since the population census in 1981, the administrative and legal criteria have used in Serbia, according to which the settlements are declared as urban by the legal regulations. The settlements have since been divided into the urban and the others.

According to the amendments to the Law on Territorial Organization of the Republic of Serbia in February 2016, Serbia has 26 cities: Sombor, Subotica, Novi Sad, Kikinda, Zrenjanin, Sremska Mitrovica, Šabac, Loznica, Pančevo, Vršac, Smederevo, Požarevac, Valjevo, Užice, Čačak, Kragujevac, Kraljevo, Jagodina, Zaječar, Kruševac, Novi Pazar, Niš, Leskovac, Pirot, Vranje, Priština and Belgrade, which has a special status as the capital city. Data taken from the population censuses was processed in Microsoft Excel 2010.

\section{RESULTS AND DISCUSSION}

In the example of the 27 cities analyzed in this survey, Table 1 shows the ratio between the number of inhabitants of the cities according to the 2011 Census and the number of inhabitants these cities should have according to an ideal rank-size rule.

Figure 1 shows the correlation between the regular rank of size and the actual number of inhabitants in cities. The blue line indicates the distribution of settlements by population size, and the red line indicates the distribution of settlements by the rank-size rule.

The Pearson's correlation coefficient between the number of inhabitants of cities according to the 2011 Census and the number of inhabitants according to the rank-size rule of cities is 0.93 , which represents a very high positive value of the match. 
Table 1. The rank-size rule for cities in Serbia, according to the 2011 Census

\begin{tabular}{|c|c|c|c|}
\hline Rank & City & $\begin{array}{l}\text { Number of inhabitants, } \\
2011\end{array}$ & $\begin{array}{l}\text { Number of inhabitants by } \\
\text { the Rank-size rule }\end{array}$ \\
\hline 1. & Belgrade & 1.394 .217 & 1.394 .217 \\
\hline 2. & Novi Sad & 221.854 & $697.108,5$ \\
\hline 3. & Niš & 187.544 & 464.739 \\
\hline 4. & Kragujevac & 147.281 & $348.554,3$ \\
\hline 5. & Priština & 145.149 & $278.843,4$ \\
\hline 6. & Subotica & 96.483 & $232.369,5$ \\
\hline 7. & Zrenjanin & 75.743 & $199.173,9$ \\
\hline 8. & Pančevo & 73.992 & $174.277,1$ \\
\hline 9. & Čačak & 72.148 & 154.913 \\
\hline 10. & Kraljevo & 63.030 & $139.421,7$ \\
\hline 11. & Smederevo & 63.028 & 126.747 \\
\hline 12. & Novi Pazar & 60.638 & $116.184,8$ \\
\hline 13. & Leskovac & 59.610 & $107.247,5$ \\
\hline 14. & Valjevo & 58.184 & $99.586,9$ \\
\hline 15. & Kruševac & 57.627 & $92.947,8$ \\
\hline 16. & Vranje & 54.456 & $87.138,6$ \\
\hline 17. & Šabac & 52.822 & $82.012,8$ \\
\hline 18. & Užice & 52.199 & $77.456,5$ \\
\hline 19. & Sombor & 47.485 & $73.379,8$ \\
\hline 20. & Požarevac & 42.963 & $69.710,9$ \\
\hline 21. & Pirot & 38.432 & $66.391,3$ \\
\hline 22. & Kikinda & 37.676 & $63.373,5$ \\
\hline 23. & Sremska Mitrovica & 37.586 & $60.618,1$ \\
\hline 24. & Zaječar & 36.830 & $58.092,4$ \\
\hline 25. & Jagodina & 36.092 & $55.768,7$ \\
\hline 26. & Vršac & 35.701 & $53.623,7$ \\
\hline 27. & Loznica & 18.714 & $51.637,7$ \\
\hline
\end{tabular}

The values of the urban primary index for the censuses between 1971 and 2011 in both ways are shown in Table 2 .

Table 2. Urban primacy index

\begin{tabular}{|c|c|c|c|c|}
\hline 1971 & 1981 & 1991 & 2002 & 2011 \\
\hline 7,371 & 6,525 & 7,772 & 7,318 & 6,284 \\
2,878 & 2,409 & 2,734 & 2,728 & 2,504 \\
\hline
\end{tabular}




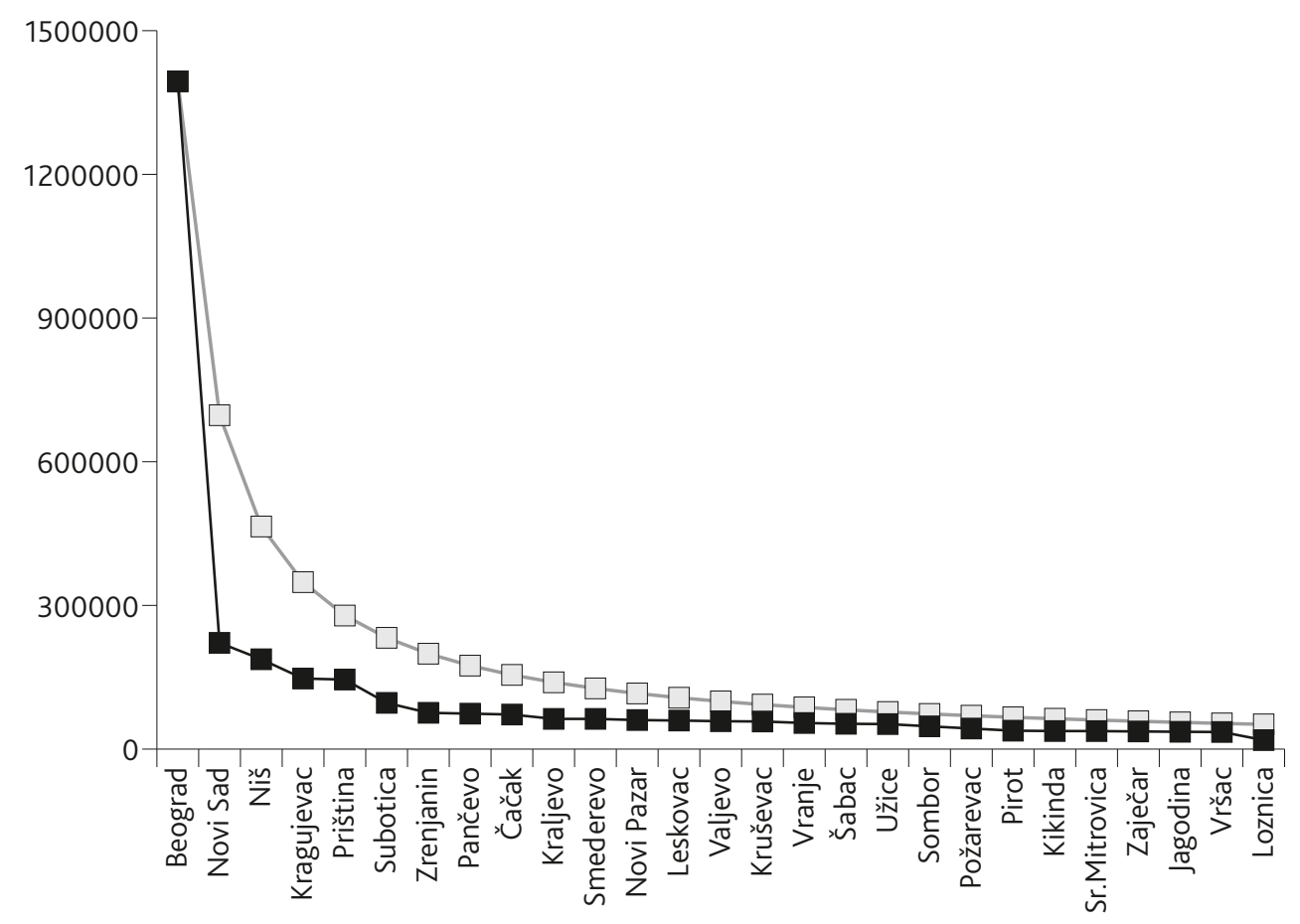

Figure 1. Graphic representation of the rank of the size of the cities in Serbia, according to the 2011 Census

The results show a very high urban primacy index, where the remaining cities in the hierarchy are lagging behind the primate city (Belgrade). Based on both equations, there is a decline in the urban primacy index between 1971 and 1981, and between 2002 and 2011.

Based on Schmook's formula for the centrality of the settlement, positive and negative values were obtained. Positive values refer to the active population in the tertiary and quaternary sectors in large cities, while those with a smaller population have negative values. The reversed situation applies in the share of the active population in the primary and secondary sectors, where the largest cities of Serbia have negative values.

Figure 2 shows a significant deviation of the city of Belgrade from other urban municipalities in the share of the active population employed in the tertiary and quaternary sectors of the economy.

For the purpose of more transparent presentation of results, Figure 3 omitted the capital city from the analysis.

Cartographic appendices include an analysis of cities represented by a symbol of a point of different colours and sizes according to the number of inhabitants in the given census. The smallest circle represents the cities with less than 25,000 inhabitants, followed by those of up to 50,000,100,000, 150,000, and over 150,000 inhabitants.

According to the Population Census of 1971, the only city with over 150,000 inhabitants is Belgrade. In the second rank are Novi Sad and Niš. They are followed by Subot- 


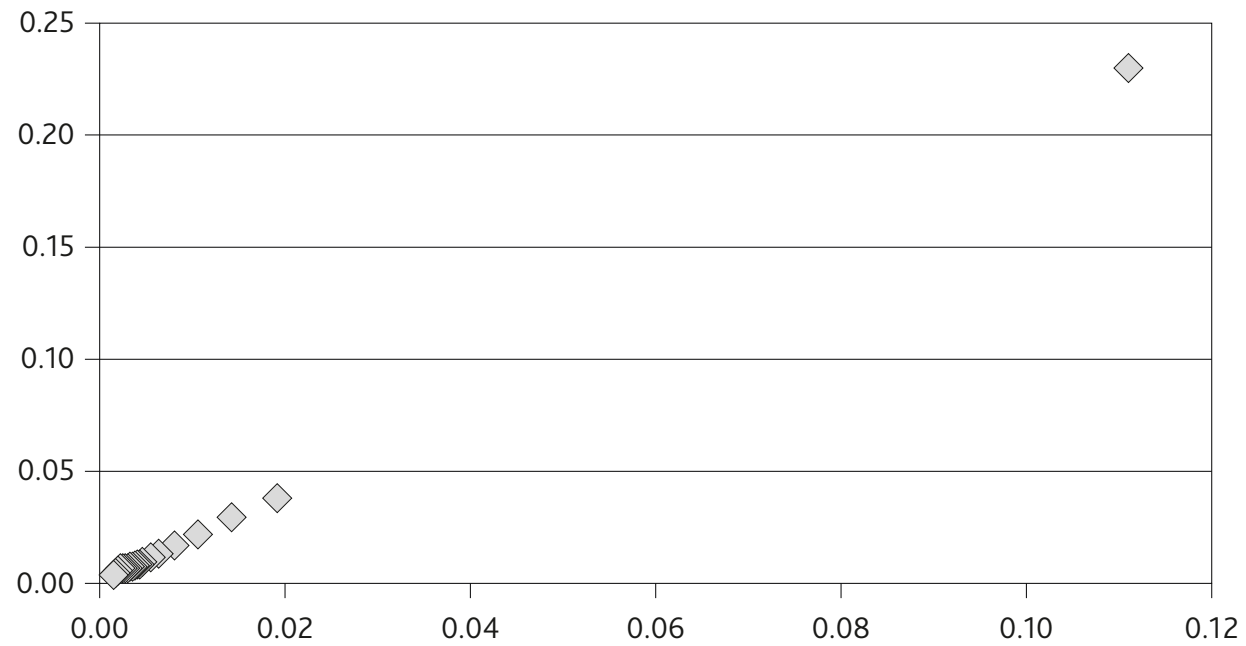

Figure 2. Centrality of settlements depicted by the Rochefort's method

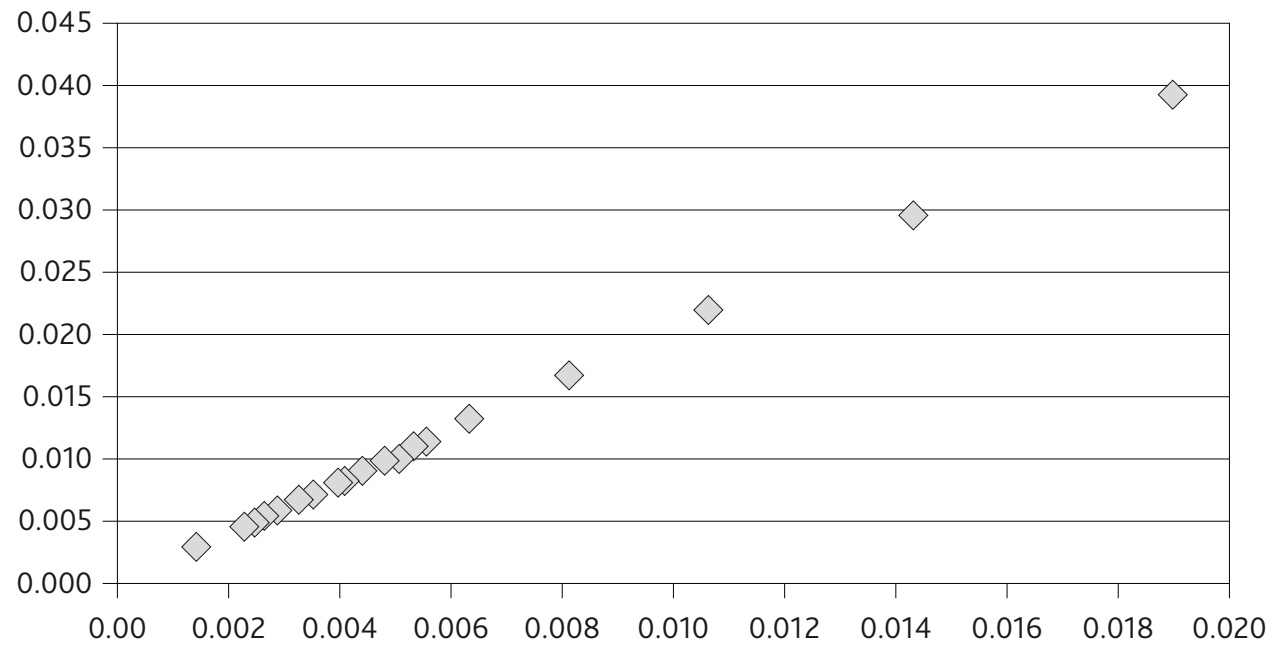

Figure 3. Centrality of settlements depicted by the Rochefort's method without Belgrade

ica, Pančevo, Priština and Zrenjanin. Most cities are in the fourth rank (18). According to the number of inhabitants, Loznica was the smallest city of that year (Appendix 1).

After ten years, the situation improved as cities of lower rank have moved to higher one. Novi Sad and Niš joined to Belgrade. Subotica, Kragujevac and Priština moved to the second rank. Šabac, Valjevo, Čačak, Kraljevo, Kruševac, Leskovac and Smederevo have over 50,000 inhabitants, while Sremska Mitrovica, Sombor, Kikinda, Vršac, Zaječar, Pirot, Vranje, Novi Pazar, Jagodina and Požarevac have no change. Loznica increases the number of inhabitants but still is the smallest city (Appendix 2). 

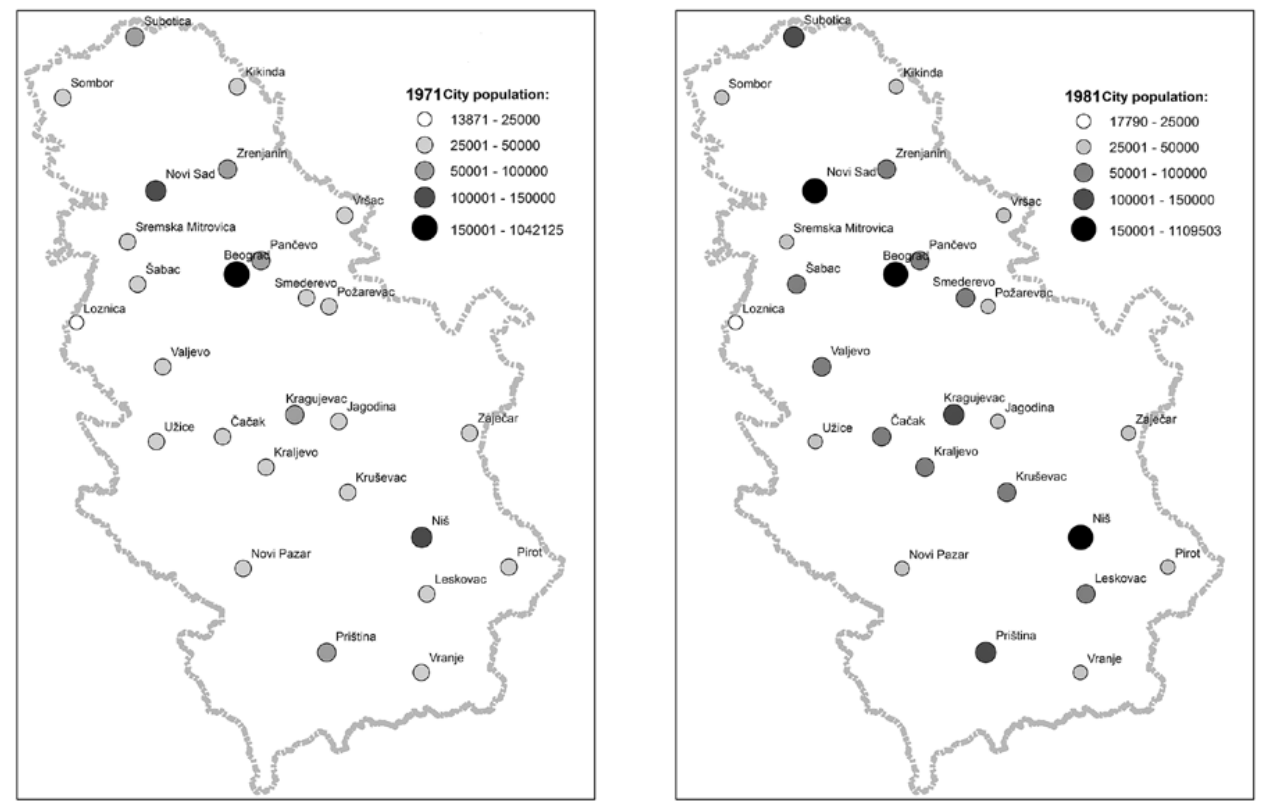

Appendices 1 and 2. Number of inhabitants in the cities of Serbia according to the censuses in 1971 and 1981

In addition to the aforementioned cities, Priština also had more than 150,000 inhabitants in the next census in 1991. Cities of the second rank now include Subotica and Kragujevac. Novi Pazar, Užice and Vranje exceed 50,001 inhabitants. Sombor, Vršac, Sremska Mitrovica, Požarevac, Zaječar, Jagodina and Pirot remain in the fourth rank, and Loznica is in the fifth (Appendix 3).

According to the 2002 census, Belgrade, Novi Sad, Kragujevac, Niš and Priština are in the first rank in terms of population. This was the census in which Serbia had the most cities in the first rank. Subotica stays alone in the second rank, and Sombor moves from fourth to third rank and joins to those listed in the previous census. In addition to Sombor, all other cities in the lower ranks are unchanged by the number of inhabitants (Appendix 4).

The situation in Serbia according to the 2011 census is as follows: Priština and Kragujevac lose the rank of the first city, so that over 150,001 inhabitants have only Novi Sad, Niš and Belgrade. In the second rank are only Priština and Kragujevac, because Subotica has a reduced number of inhabitants compared to the previous census. Subotica, Zrenjanin, Šabac, Pančevo, Smederevo, Valjevo, Užice, Čačak, Kraljevo, Kruševac, Novi Pazar, Vranje and Leskovac are in the third rank, that is, they have over 50.000 inhabitants. Less than this number have Sombor, Kikinda, Vršac, Sremska Mitrovica, Požarevac, Zaječar and Pirot. Loznica remains the city with the smallest number of inhabitants throughout the observed period (Appendix 5). 

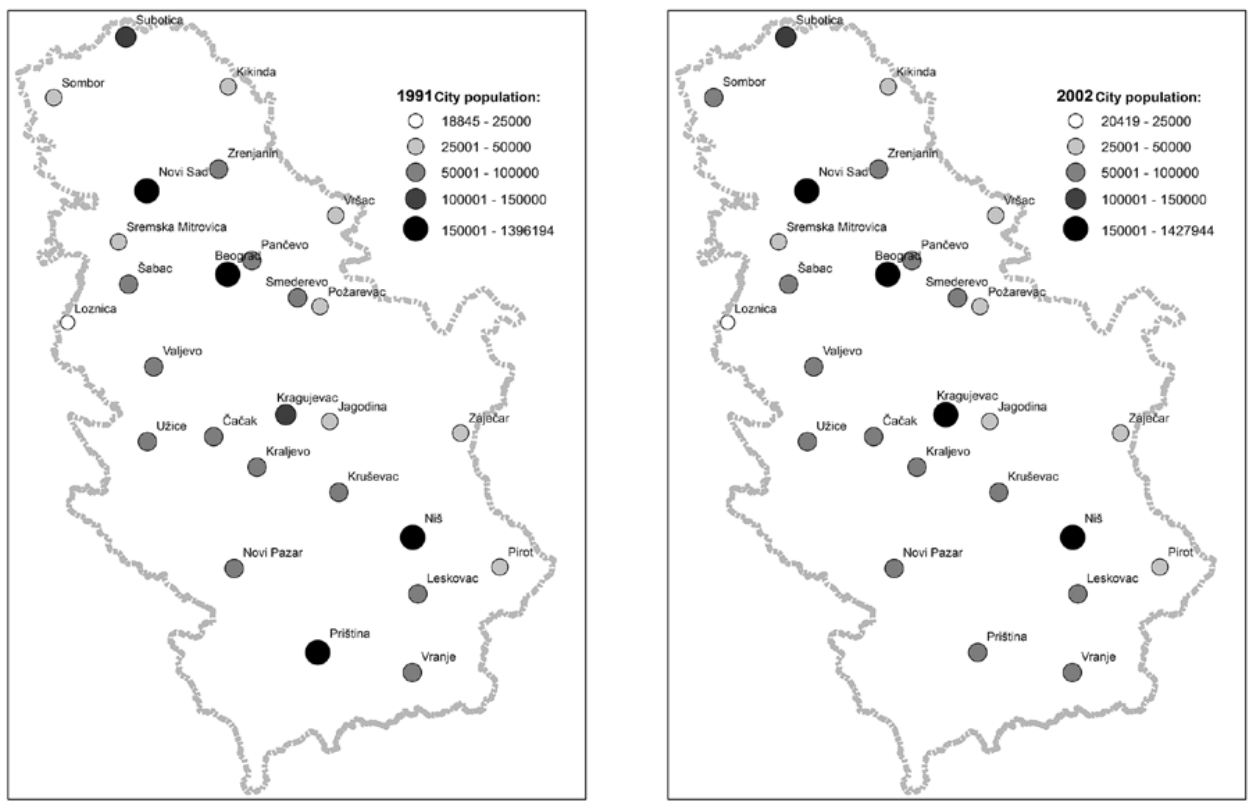

Appendices 3 and 4. Number of inhabitants in the cities of Serbia according to the censuses in 1991 and 2002

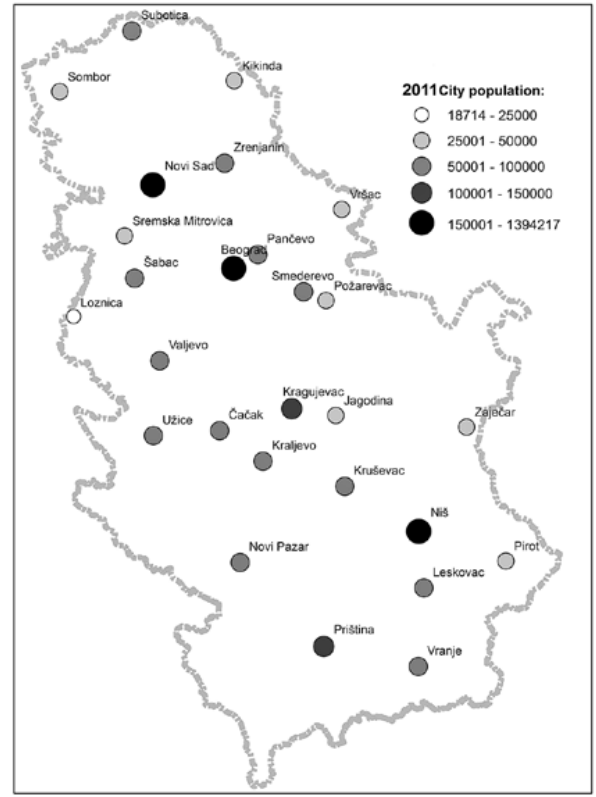

Appendices 5. Number of inhabitants in the cities of Serbia according to the censuses in 2011 


\section{CONCLUSION}

Cities on the territory of today's state of Serbia have existed from the Roman period. Over time, the significance of certain cities has changed in line with historical, political and social changes changing their hierarchy.

According to the Rank-size rule, Novi Sad, as the second city in the hierarchy, has three times smaller number of inhabitants than it should, and this is the biggest deviation. A similar situation occurs in other cities, where, according to the expected rank of size, cities in Serbia have considerably fewer inhabitants. Of the 26 cities analyzed, Vršac has the smallest difference between the expected and the actual number of inhabitants compared to the rank in the hierarchy.

During the analyzed censuses, urban primacy was constantly greater than 6 , which highlights the difference between Belgrade and other cities in Serbia.

According to Schmook's method of determining the centrality of the settlements, the largest positive values of the active population employed in the tertiary and quaternary sectors were recorded for the largest cities (Novi Sad, Belgrade, Niš). The lowest negative values were recorded in Vranje, Šabac and Kruševac.

The cities that have according to the latest census over 150,000 residents are Novi Sad, Belgrade and Niš, which is less than in 2002, when this category included Kragujevac and Priština.

\section{REFERENCES}

Jefferson, M. (1939) 'The law of the primate city', Geographical Review, 29(2), 226-232.

Nicholson, J. P. (2003) 'Why Do So Many Developing Countries Have Primate Cities?' In: Urbanization in the Context of Development, Middlebury College 2003 Conference.

Murray, M. (2003) 'On Urban Primacy', In: Urbanization in the Context of Development, Middlebury College 2003 Conference.

Mutlu, S. (1989) 'Urban Concentration and Primacy Revisited: An Analysis and Some Policy Conclusions'. In: Economic Development and Cultural Change, Vol. 37, No. 3 April 1989, pp. 611-613.

Berry, B. J. L; Garrison, W. L. (1959): "Alternate Explanations of Rank-size Relations", In: Mayer, H. M.; Kohn, C. F. (eds.), Readings in Urban Geography. The University of Chicago Press,Chicago pp. 230-239

Soo, T. K. (2002): “Zipf's Law of Cities: A Cross Country Investigation", Regional Science and Urban Economics Volume 35, Issue 3, May 2005, Pages 239-263

Sarkar, S. and Maji, S. (2013), An Analysis of Urban Primacy: The Case of Kolkata, Indian Journal of Applied Research, 3(3), 158-162.

Yousuf, T., Shah, S. A. (2014). An analysis of urban primacy in Himalayan settlements: the case of Srinagar City of Jammu \& Kashmir, International Journal of Recent Scientific Research Vol. 5, Issue, 9, pp.1670-1674, 
Бубало-Живковић, М. (2016). Урбани развој Србије, Природно-математички факултет, Департман за географију, туризам и хотелијерство, Нови Сад http:// www.dgt.uns.ac.rs/download/urbrazvojl.pdf

Ћурчић, С. (1992). Географија насеља, Природно-математички факултет, Институт за географију, Нови Сад.

Vujnić, A. (2014). Regional development indicators, case study- Serbia, Researches Reviews of the Department of Geography, Tourism and Hotel Management, 43 -1, pp. 28 41.

Аничић, Ј., Лакета, М., Вукотић, С. (2011). Инвестициона политика и регионални развој Србије у транзиционом периоду, Београд.

Schmook, G. (1968). Wiskundig afgebakene ommelanden en hinetrlanden van de Belgische steden op de basis van geselektioneerde diensten uit de tertiare sektor, Geografische Tijdschrift.

Rochefort, M. 1957: Méthodes d'étude des réseaux urbains: intérêt de l'analyse du secteur tertiaire de la population active. Annales de géographie 66-354. 


\title{
УРБАНА ХИЈЕРАРХИЈА У СРБИЈИ
}

\author{
Бојан Ђерчан, Милица Радаковић, Милош Остојић, \\ Маја Мирковић, Смиљка Обренов, Јан Возар' \\ Примљено: 10.01.2017. | Прихваћено: 21.06.2017.
}

\begin{abstract}
АПСТРАКТ: Упркос многобројним урбаним студијама које су анализирале различите аспекте урбане мреже Србије, мало пажње је посвећено испитивању феномена урбане хијерархије и урбане примарности. Стога је циљ овог рада да испита природу, ниво и прогресију урбане хијерархије у Србији, као и њене узроке и последице. У постизању ових циљева, рад почиње прегледом урбанизације у Србији и методима њеног мерења, а затим следи дискусија добијених резултата. У раду су коришћени подаци Републичког завода за статистику о броју становника и активном становништву запосленом у терцијарно-квартарном сектору од 1971. до 2011. године. У раду су тестирани Правило реда величине (Rank-size rule), познато и као Цифов закон (Zipf law), Закон примарног града (Urban primacy index), те Шмуков (Schmook) и Рошфортов (Rochefort) метод за приказивање резултата. Овим радом се дошло да закључка да је урбана примарност очигледан феномен у Србији. Јасно су изражене разике између полицентрично урбанизоване Војводине, нешто слабије урбанизоване централне Србије као и великог распона између функцијског капацитета Београда.
\end{abstract}

Кључне речи: Србија, урбанизација, централитет, хијерархија, градови

\section{УвОД}

Ефикасност урбаног система у било којој земљи у великој мери зависи од расподеле у величини и удаљености урбаних центара. На тај начин се одређује да ли је процес урбанизације једнак у целом региону или је централизован (Nicholson, 2003). Образац урбанизације у Србији углавном је био оријентисан на веће градове.

У Републици Србији су у току интензивни процеси депопулације и демографског старења, уз наглашене регионалне диспропорције становништва. Интензивне миграције резуртирале су концентрацијом становништва у свим већим градским срединама и депопулацијом великих пространстава Републике Србије.

\footnotetext{
' Природно-математички факултет, Универзитет у Новом Саду, Трг Доситеја Обрадовића 3, 21000 Нови Сад, Србија, контакт: dgt.milica.radakovic@student.pmf.uns.ac.rs
} 
Изражена регионална неравномерност између недовољно развијеног, већег дела простора и развијених територијалних подручја и сегмената Републике Србије, резултанта је заједничког деловања бројних фактора и њихових узрочно-последичних односа (Vujnić, 2014).

Широк спектар наслеђених културно-историјских, демографских, економских, инфраструктурних, социјалних и политичких параметара, уважавајући свакако, природни и геостратешки положај појединих области, пресудно су утицали на неравномеран регионални развој наше земље. Последице на простору Републике Србије су евидентне - огромни унутаррегионални и међурегионални несклади спутавају развој и подстичу миграционе токове. Велики и стратешки важни простори Републике Србије остали су популационо непокривени, а њихови ресурси неискоришћени. Истовремено, у развијенијим центрима дошло је до прекомерне концентрације становништва и привреде, што је на својевртан начин произвело негативне последице у економској, социјалној, просторној и еколошкој сфери истих (Аничић, Лакета, Вукотић, 2011).

На први поглед може се рећи да урбану мрежу Србије карактерише повољан размештај градских насеља, али мало подробнија анализа о концентрацији становништва и функција у њима отвара одређене проблеме. У Београду живи око $26 \%$ урбаног становништва Србије без Космета. На његову доминантност указује индекс урбане примарности чија је вредност 6,3 (однос броја становника Београда и Новог Сада). Несклад између становништва водећег и осталих градских насеља говори да Србија нема правилно и равномерно развијен урбани систем, тј. да токови урбанизације нису правовремено усмеравани.

У Србији су издиференцирани бројни облици мање и више урбанизованих ареала и више облика регионалних урбаних система и успостављено њихово просторно и функционално устројство. Међутим, Србија је недовољно урбанизована, а у погледу континуитета трајања и просторних форми испољавања урбанизације јасно су изражене разлике између полицентрично урбанизоване Војводине, нешто слабије урбанизоване централне Србије, са неправилном хијерархијском структуром у системима градских насеља и великим распоном између функцијског капацитета Београда и других центара и нискоурбанизованог простора Косова и Метохије (Ћурчић, 1992).

Иако се велики број аутора, који се баве урбаним процесима и урбаним структурама, кроз своје радове залагао за полицентричан и уравнотежен развој мреже градских насеља, тај концепт у пракси регионалног планирања и регионалног развоја није остварен. Тек је током израде Просторног плана Републике извршена егзактна анализа свих елемената и фактора регионалног развоја, на којој је утемељена стратегија чијим провођењем ће се извршити деметрополизација београдске агломерације, ублажити дисфункционалност у систему насеља и започети функционално уравнотежење. 


\section{ПРЕГЛЕД УРБАНИЗАЦИЈЕ У СРБИЈИ}

Главна насеља у Србији су углавном римског и византијског порекла, а нека и са старијим основама из праисторијског доба. Најстарије насеобине на овом простору потичу из мезолита, а познатије културе су Лепенски вир, Старчево и Винча. Градови који се јављају за време Римске империје су: Sirmium (Сремска Митровица), Singidunum (Београд), Naisus (Ниш), Viminacium (Костолац), Horeum Margi (Ћуприја), Ulpiana (Грачаница), Kapedunum (Ужице), Remeziana (Бела Паланка), Iustinijana Prima (Царичин град код Лебана) и други. За време ратова многе до тада веће вароши губиле су на значају, или су у потпуности нестајале, да би се првом приликом обнављале.

Почетком средњег века и у турском периоду одржале су се оне вароши које су имале најповољнији географски положај. Такви су били Београд, Ниш, Смедерево, Крушевац, Приштина. Повољни услови су били поред већих река (Дунава, Саве, Тисе, Мораве), а туда су водили и главни путеви тог времена. Знатан део данашњих градова заснован је на темељима градова који се помињу у средњевековним повељама и изворима. Неки од њих су Београд, Шабац, Ваљево, Смедерево, Ужице, Јагодина, Ниш, Чачак, Крушевац, Приштина. У време Аустријско-турских ратова градови Србије су више пута потпадали под аустријску односно турску власт. Примат су преузимали градови на границама као места где се развијала трговина. Ако је околина била економски снажна и ако је варошица основана на раскрсници важних путева, она је често у кратком временском периоду постајала трговачки снажна (Обреновац, Младеновац).

Градско становништво је било малобројно. Године 1834. тај број је износио само 41.347 становника и споро је растао. Београд је 1874. године имао свега 27.605 становника. Постојала је битна етничка и верска разлика између сеоског и градског становништва. Густина насељености у Кнежевини Србији 1834. године износила је $18 \mathrm{cт} / \mathrm{km}^{2}$, а 1874. године $36 \mathrm{cт} / \mathrm{km}^{2}$. Због високог природног прираштаја и досељавања, густина насељености се повећава на 56 ст $/ \mathrm{km}^{2}$. У Војводини је 1880 . године густина насељености била $53 \mathrm{cт} / \mathrm{km}^{2}$, а 1910. године $68 \mathrm{cт} / \mathrm{km}^{2}$. Између два светска рата је повећана са 51 ст $/ \mathrm{km}^{2}$ 1921. године на 72,5 ст/ $\mathrm{km}^{2} 1940$. године. За време Другог светског рата неки војвођански градови губе велики број становника (Вршац, Сента и Сремска Митровица), због окупаторског терора, прогона Јевреја (Сента, Нови Сад) и исељавања Немаца (Вршац) (Бубало-Живковић, 2016).

Развој насељености током 19. века и у првој половини 20. века показује особине типичне за аграрну средину веома ниског степена урбанизације и високе аграрне пренасељености. Миграције су процес који је изазвао највеће разлике у демографском развоју руралних и урбаних подручја. Миграције село-град пореметиле су постојећу равнотежу и релативну независност демографског развоја стварајући с једне стране депопулацију и пражњење руралних области, а са друге стране повећавање броја становника у градским срединама. До пораста градског становништва дошло је и услед природног прираштаја, али и промене статуса одређених насеља. По попису становништва 1953. године у градским насељима живело је око једне петине укупног становништва $(22,5 \%)$, а око две трећине ак- 
тивног становништва (67\%) било је пољопривредно. Војводина је била најурбанизованија са 29,5\% градског становништва, затим централна Србија са 21,2\% и на крају Косово и Метохија са само 14,6\%. У раздобљу 1961 - 1971. година, стопа раста градског становништва износи 4,2\%, а степен урбанизације је порастао на 40,6\% (централна Србија 40,8\%, Војводина 48,8\%, Косово и Метохија 26,9\%). Између 1971. и 1981. године, стопа раста опада на $2,4 \%$, а учешће градског становништа у укупном се повећало на 46,6\% (централна Србија 47,8\%, Војводина $54,1 \%$, Косово и Метохија 32,5\%). У периоду 1981 - 1991. година стопа раста је нижа - 1,4\%, док је степен урбанизације повећан на 50,7\% (централна Србија 53,5\%, Војводина 55,7\%, Косово и Метохија 37,5\%). За то време градска популација увећана је за 91.386 становника, док је популација осталих насеља смањена за 161.000 становника.

Просторна и социјална покретљивост становништва из сеоских у градска насеља и из примарног у секундарни и терцијарни сектор делатности утицала је на сукцесију фаза урбанизације, што се територијално и временски испољавало демографским, функционалним и физиономским променама како градских тако и сеоских насеља.

Сложени урбани системи сачињени су од више насеља чије су везе последица интеракције њихових структурних елемената и различитог степена хијерархије. Имају карактер функционалноурбаних тј. метрополитанских регија. Одликују се високим степенима урбанизације и великим учешћем градског становништва у укупном, великом запосленошћу радне снаге у непољопривредним делатностима, диверсификованим функцијама и стабилном дневном миграцијом радне снаге. Најзначајнији представници тог типа урбаних система су Нови Сад, Ниш, Крагујевац и Суботица (Бубало-Живковић, 2016).

Београдска агломерација је сложен и динамичан систем урбаних насеља високог степена функционалне и морфолошке повезаности са јасно израженом вишеслојном хијерархијом и великим гравитационим утицајем који превазилази границе државе. Београд је потенцијални центар Југоисточне Европе прворазредног међународног значаја односно средиште будућег еврометрополитанског региона. Град Београд имао је према Попису из 2002. године 1.574 .050 становника, од којих је у градским насељима било 1.280.639 становника, односно 82,3\%. По подацима последњег пописа из 2011. године у београдском региону је живело 1.659.440 становника, од којих градско чини 1.344 .844 или $81 \%$.

Као велико агломерацијско језгро Војводине, Нови Сад је значајан део конурбације која се шири ка Београду. То је град који последњих деценија има значајан пораст броја становника и то углавном захваљујући миграционим процесима. Он је 2002. године имао 299.294 становника, а 2011. године 377.522 становника.

Град Ниш има 260.237 становника, од којих у градским насељима (Ниш и Нишка Бања) живи 187.544 становника. Ако би се при одређивању граница нишке агломерације применио социогеографски метод, утврдило би се да је Ниш средиште полицентричне метрополитанске регије која има преко 350.000 становника и велику зону утицаја (Бубало-Живковић, 2016). 


\section{МЕТОДОЛОГИЈА}

Предмет истраживања су насеља Србије која од фебруара 2016. године носе статус града. Циљ истраживања јесте утврђивање урбане хијерархије и добијање потпуне слике о урбанизацији Србије користећи се подацима пописа становништва, почев од 1971. године, закључно са последњим пописом који је спроведен 2011. године. Задатак истраживања јесте анализирати бројеве становника за сваки град појединачно кроз раније поменуте пописе, донети закључке о флуктуацијама бројева, имајући у виду историјске догађаје и економске, социолошке и друге узрочнике.

За обраду података кориштене су статистичке, картографске, математичке, демографске и компаративне методе. У софтверу ArcMap 10.1. дигитализована је карта Србије у циљу графичког приказивања резултата.

Правило реда величине први је уочио немачки географ Ауербах почетком двадесетог века. Правило се односи на постојање зависности између величине и броја градова, односно да се јавља тенденција настанка правилног реда величине градова у простору. Та су запажања после разрадили многи аутори: Циф, Стјуарт, Сингер, Бери. Они су међузависност теоретски формулисали као Правило реда величине (Berry, Garrison, 1959; Soo, 2002). Према овом параметру, може се очекивати да ће један град у низу градова неке земље или регије, поређаних по величини, имати онолики број становника колико има највећи град, подељен са редним бројем тог града у низу градова. Дакле, друго насеље у низу имаће упола мање становника од највећег, трећи ће имати за трећину мање од највећег итд. Одређивање правила реда величине броја становника по градовима познато и као Цифов закон одређује се формулом:

$$
S_{n}=\frac{S_{1}}{r}
$$

где је $S_{n}$ - очекивани број становника града у хијерархији, $S 1$ - број становника највећег града, a $r$ - редни број града у низу. Дистрибуција насеља се најчешће приказује графиконом са аритметичком скалом на којој функција има облик криве. На основу Пирсоновог коефицијента корелације се може одредити степен подударности дистрибуције насеља.

Амерички географ Џеферсон (Jefferson, 1939) је приметио да се у појединим земљама величином истиче главни град - примарни град, а остали градови су знатно мањи и ту појаву је назвао Закон примарног града. Многи научници сматрају да је то последица политичких и економских прилика, и изузетног политичког, привредног и друштвеног значаја главног града (Mutlu, 1989; Murray, 2003; Sarkar, Maji, 2013; Yousuf, Shah, 2014). Закон примарног града се рачуна на основу индекса урбане примарности:

$$
I=\frac{G_{1}}{G_{2}}
$$


где је $I$ - индекс урбане примарности, $G 1$ - број становника навећег града и $G 2$ број становника другог града по величини. У пракси се најчешће за израчунавање узимају три највећа града по величини:

$$
I=\frac{G_{1}}{G_{2}+G_{3}+G_{4}}
$$

Урбана примарност је велика ако је добијена вредност индекса већа од 2.

Један од истраживачких поступака за утврђивање степена развоја, положаја и значаја насеља у мрежи је Шмуков метод за централитет насеља (Schmook, 1968). Њиме се централитет израчунава као однос броја активног становништва запосленог у терцијарно-квартарном сектору у укупном активном становништву региона. Централитет се израчунава према обрасцу:

$$
C_{1}=A_{n} \cdot \frac{T Q_{n}}{A_{n}}-\frac{T Q_{r}}{A_{r}}
$$

где је $A_{n}$ - активно становништво у насељу, $T Q_{n}$ - активно становништво запослено у терцијарно- квартарном сектору у насељу, $T Q_{r}-$ активно становништво у терцијарно - квартарном сектору у региону и $A_{r}$ - активно становништво у региону.

Рошфортов метод даје могућност графичког приказивања централитета насеља помоћу формуле (Rochefort, 1957):

$$
X=\frac{T Q_{n}}{A_{r}}, \frac{T Q_{n}}{T Q_{r}}
$$

Ознаке у обрасцу имају исто значење као у Шмуковом моделу, а Х и Ү су апсциса, односно ордината координатног система.

Према пописима становништва 1953., 1961. и 1971. године постојала је подела насеља на основу демографско-статистичког критеријума у односу на број становника и проценат непољопривредног становништва насеља. На тим пописима је важила подела на градска, мешовита и сеоска насеља. Градска насеља су могла имати најмање 2.000 становника и то само уколико су поред тога имали и преко 90\% непољопривредног становништва.

Од пописа становништва 1981. године у Србији се користи административно-правни критеријум по коме се насеља законским прописима проглашавају за градска. Насеља се од тад деле на градска и остала.

Према изменама и допунама Закона о територијалној организацији Републике Србије донетом фебруара 2016. године, Србија има 26 градова: Сомбор, Суботица, Нови Сад, Кикинда, Зрењанин, Сремска Митровица, Шабац, Лозница, Панчево, Вршац, Смедерево, Пожаревац, Ваљево, Ужице, Чачак, Крагујевац, Краљево, Јагодина, Зајечар, Крушевац, Нови Пазар, Ниш, Лесковац, Пирот, Врање, Приштина, и Београд који има посебан статус као главни град. Подаци преузети из пописа становништва су обрађени у програму Microsoft Excel 2010. 


\section{РЕЗУЛТАТИ И ДИСКУСИЈА}

На примеру 27 градова анализираних у овом истраживању, у табели 1 су приказани однос између броја становника градова према Попису из 2011. године и броја становника који би требали имати према идеалном правилу реда величине.

Табела 1. Правило реда величине за градове у Србији, према Попису 2011. године

\begin{tabular}{|c|c|c|c|}
\hline $\begin{array}{l}\text { Редни } \\
\text { број }\end{array}$ & Град & Број становника 2011. & $\begin{array}{l}\text { Број становника према } \\
\text { Правилу реда величине }\end{array}$ \\
\hline 1. & Београд & 1.394 .217 & 1.394 .217 \\
\hline 2. & Нови Сад & 221.854 & $697.108,5$ \\
\hline 3. & Ниш & 187.544 & 464.739 \\
\hline 4. & Крагујевац & 147.281 & $348.554,3$ \\
\hline 5. & Приштина & 145.149 & $278.843,4$ \\
\hline 6. & Суботица & 96.483 & $232.369,5$ \\
\hline 7. & Зрењанин & 75.743 & $199.173,9$ \\
\hline 8. & Панчево & 73.992 & $174.277,1$ \\
\hline 9. & Чачак & 72.148 & 154.913 \\
\hline 10. & Краљево & 63.030 & $139.421,7$ \\
\hline 11. & Смедерево & 63.028 & 126.747 \\
\hline 12. & Нови Пазар & 60.638 & $116.184,8$ \\
\hline 13. & Лесковац & 59.610 & $107.247,5$ \\
\hline 14. & Ваљево & 58.184 & $99.586,9$ \\
\hline 15. & Крушевац & 57.627 & $92.947,8$ \\
\hline 16. & Врање & 54.456 & $87.138,6$ \\
\hline 17. & Шабац & 52.822 & $82.012,8$ \\
\hline 18. & Ужице & 52.199 & $77.456,5$ \\
\hline 19. & Сомбор & 47.485 & $73.379,8$ \\
\hline 20. & Пожаревац & 42.963 & $69.710,9$ \\
\hline 21. & Пирот & 38.432 & $66.391,3$ \\
\hline 22. & Кикинда & 37.676 & $63.373,5$ \\
\hline 23. & Сремска Митровица & 37.586 & $60.618,1$ \\
\hline 24. & Зајечар & 36.830 & $58.092,4$ \\
\hline 25. & Јагодина & 36.092 & $55.768,7$ \\
\hline 26. & Вршац & 35.701 & $53.623,7$ \\
\hline 27. & Лозница & 18.714 & $51.637,7$ \\
\hline
\end{tabular}

На графикону 1 је приказана корелација између правилног реда величине и стварног броја становника у градовима. Плава линија означава дистрибуцију насеља према популационој величини, а црвена линија означава дистрибуцију насеља према правилу реда величине. 


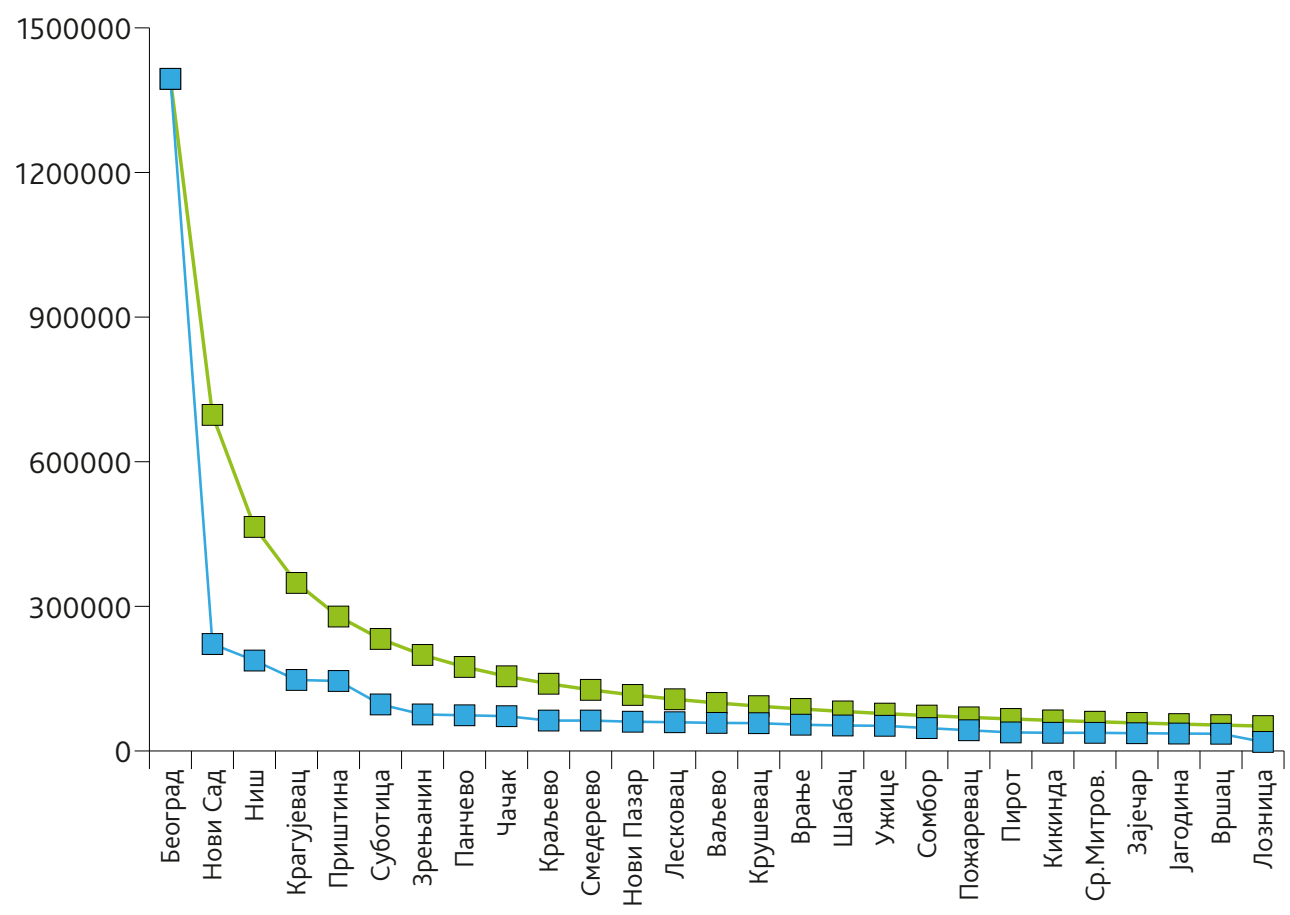

Графикон 1. Графички приказ реда величине градова у Србији, према Попису 2011. године

Пирсонов коефицијент корелације између броја становника градова према Попису из 2011. године и броја становника према правилу реда величине градова износи 0,93 што представља веома високу позитивну вредност подударања.

Вредности индекса урбане примарности за пописе од 1971. до 2011. године на оба начина приказане у табели 2 .

Табела 2. Индекс урбане примарности

\begin{tabular}{|l|l|l|l|l|}
\hline 1971 & 1981 & 1991 & 2002 & 2011 \\
\hline 7,371 & 6,525 & 7,772 & 7,318 & 6,284 \\
2,878 & 2,409 & 2,734 & 2,728 & 2,504 \\
\hline
\end{tabular}

Резултати до којих се дошло показују веома висок индекс урбане примарности, где за примарним градом (Београд) вишеструко заостају остали градови у хијерархији. На основу обе формуле примећују се опадања индекса урбане примарности између 1971. и 1981. године, и између 2002. и 2011. године.

Према Шмуковој формули за централитет насеља, добијане су позитивне и негативне вредности. Позитивне вредности се односе на активно становништво у терцијарном и квартарном сектору у великим градовима, док они са мањим бројем становника имају негативне вредности. Обрнута ситуација је у уделу ак- 


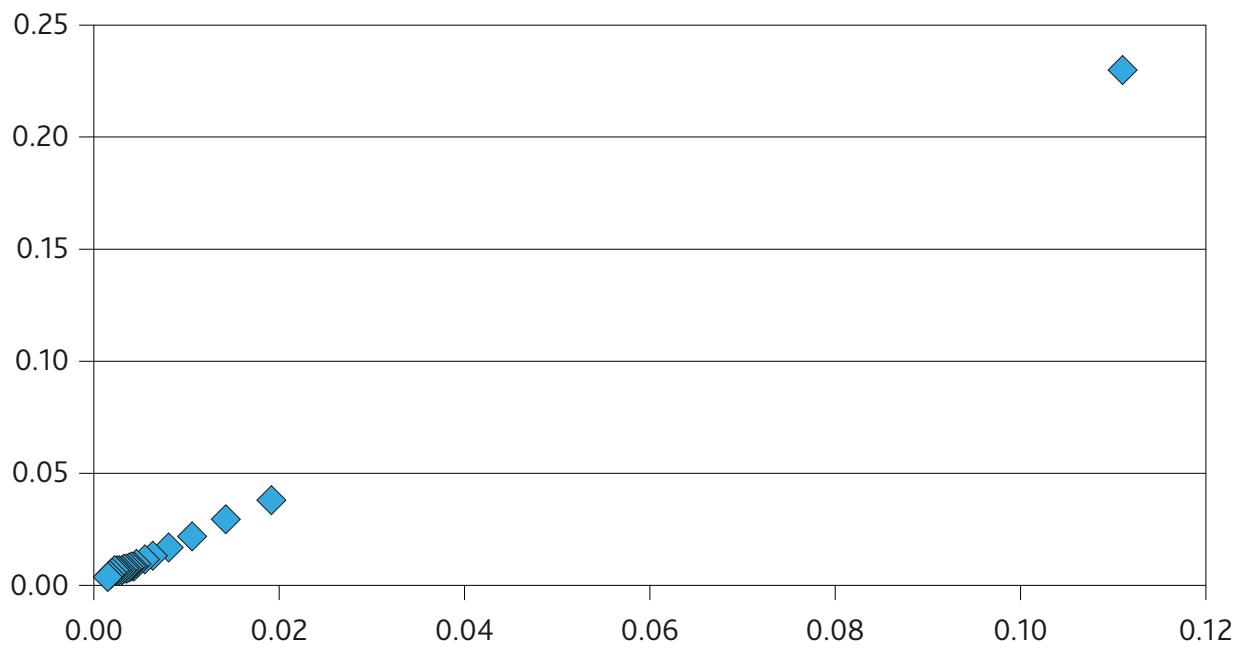

Графикон 2. Централитет насеља приказан Рошфортовим методом

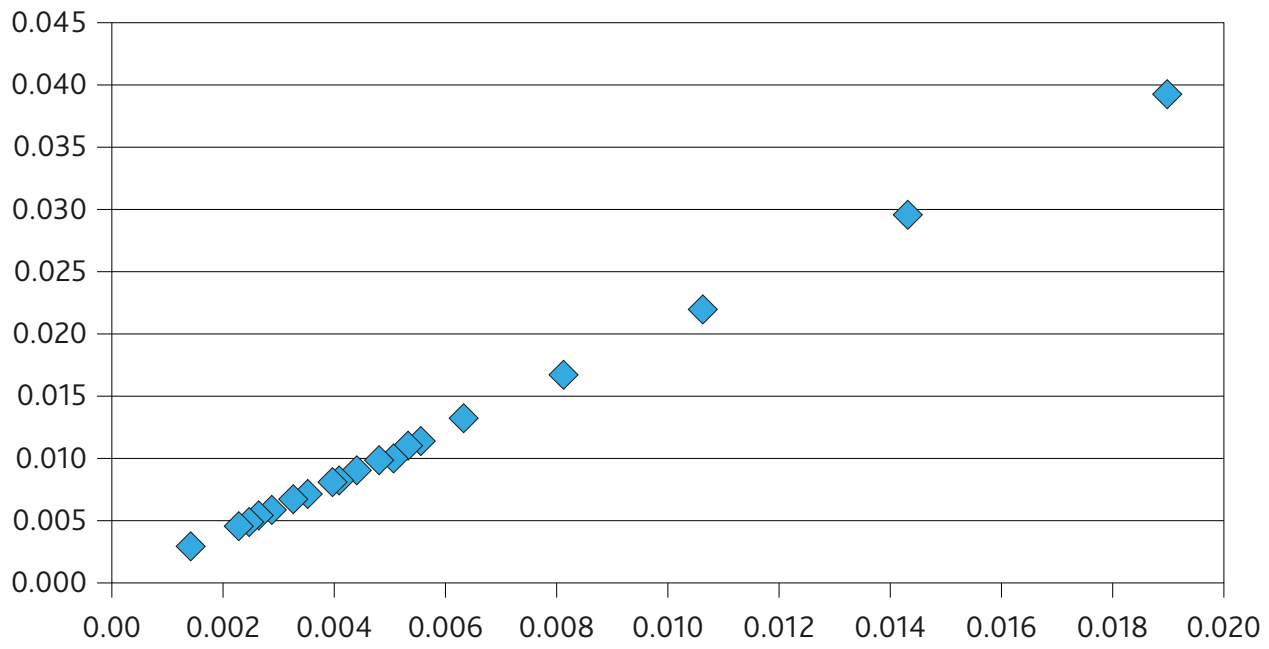

Графикон 3. Централитет насеља приказан Рошфортовим методом, без Београда

тивног становништва у примарном и секундарном сектору, где највећи градови Србије имају негативне вредности.

На графикону 2 се може уочити знатно одступање града Београда од осталих градских општина у уделу активног становништва запосленог у терцијарном и квартарном сектору привреде.

У циљу прегледнијег приказивања резултата, на графикону 3 је главни град изостављен из анализе.

На картографским прилозима су анализирани градови приказани симболом тачке различите боје и величине у складу са бројем становника у датом попису. 
Најмањи круг представљају градови са мање од 25.000 становника, затим иду они до $50.000,100.000,150.000$, и преко 150.000 становника.

Према Попису становништва из 1971. године једини град који има преко 150.000 становника је Београд. У другом рангу су Нови Сад и Ниш. Њих следе Суботица, Панчево, Приштина и Зрењанин. Највише градова је у четвртом рангу (18). Лозница је по броју становника те године била најмањи град (прилог 1).

За десет година ситуација се побољшала јер су градови нижег ранга прешли у виши. Београду се придружују Нови Сад и Ниш. Суботица, Крагујевац и Приштина прелазе у други ранг. Шабац, Ваљево, Чачак, Краљево, Крушевац, Лесковац и Смедерево имају преко 50.000 становника, док Сремска Митровица, Сомбор, Кикинда, Вршац, Зајечар, Пирот, Врање, Нови Пазар, Јагодина и Пожаревац немају промену. Лозница повећава број становника али је и даље најмањи град (прилог 2).

Поред споменутих градова, више од 150.000 становника у следећем Попису 1991. године има и Приштина. У градове другог ранга сада спадају Суботица и Крагујевац. Нови Пазар, Ужице и Врање прелазе 50.001 становника. У четвртом рангу остају Сомбор, Вршац, Сремска Митровица, Пожаревац, Зајечар, Јагодина и Пирот, а Лозница је у петом (прилог 3).

Према попису из 2002. године у први ранг према броју становника спадају Београд, Нови Сад, Крагујевац, Ниш и Приштина. То је попис у коме је Србија имала највише градова у првом рангу. Суботица остаје сама у другом рангу, а Сомбор прелази из четвртог у трећи и придружује се набројаним у претходном попису. Осим Сомбора, сви остали градови у нижим ранговима су непромењени по бројности становника (прилог 4).
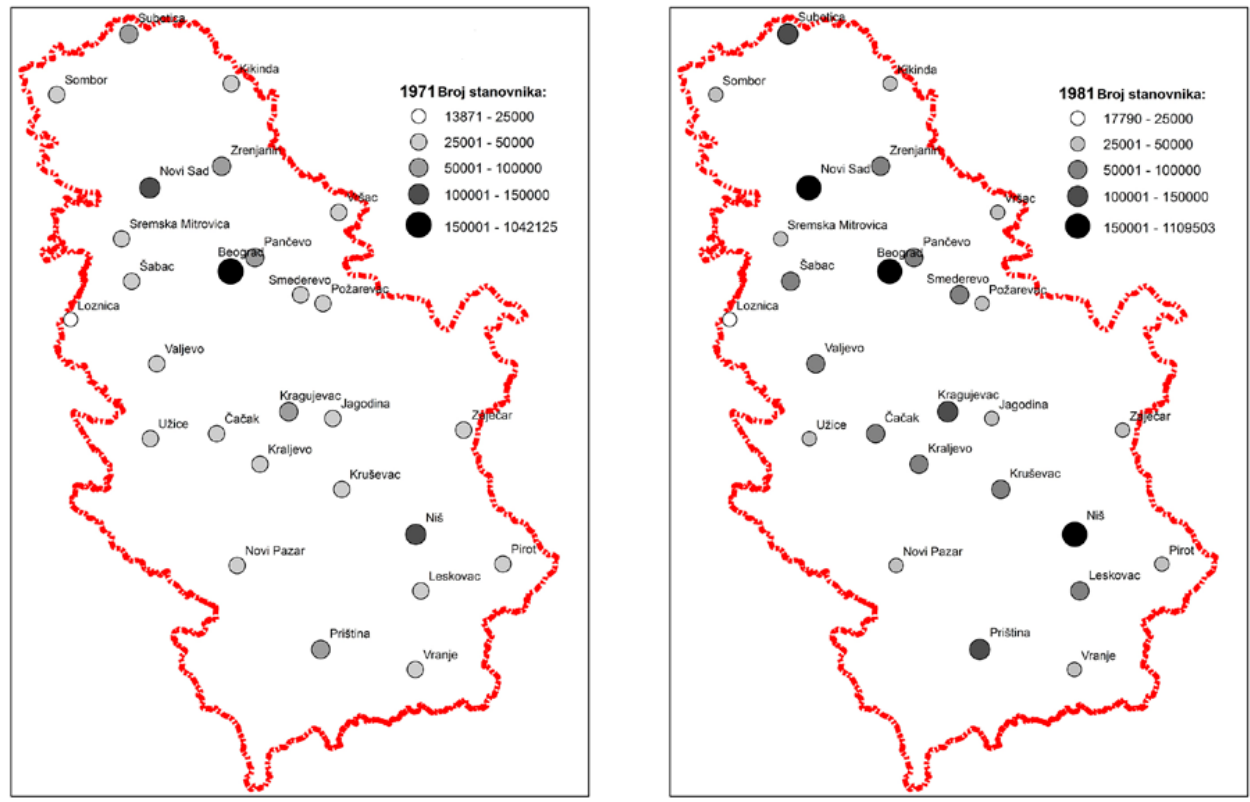

Прилог 1 и 2. Број становника у градовима Србије према попису из 1971. и 1981. године 

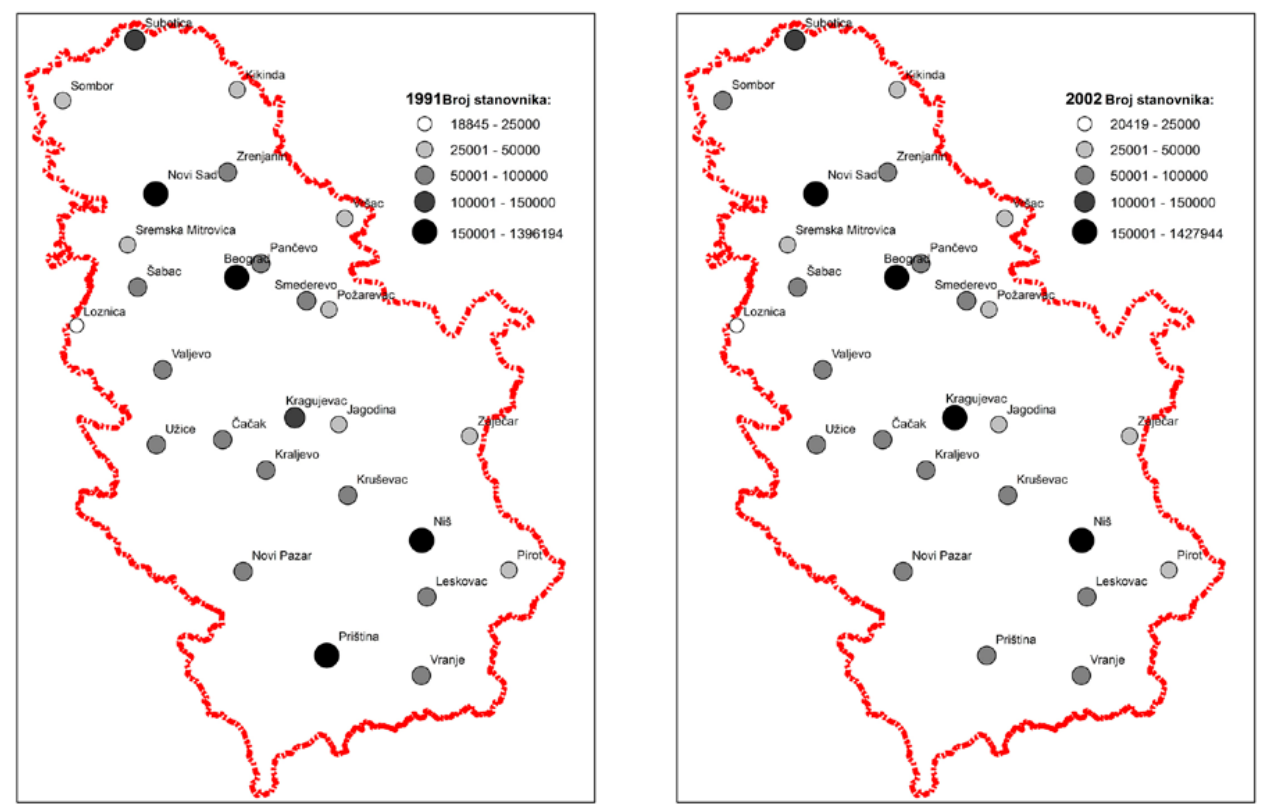

Прилог 3 и 4. Број становника у градовима Србије према Попису из 1991. и 2002. године

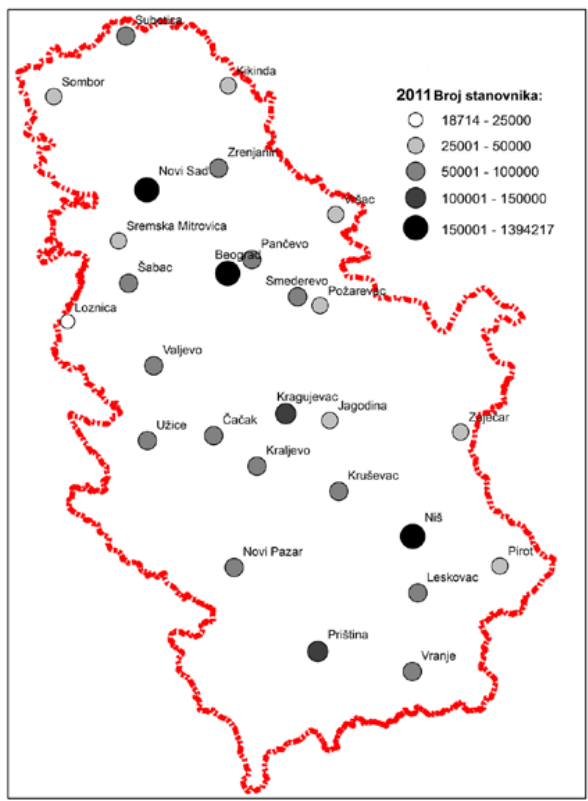

Прилог 5. Број становника у градовима Србије према попису из 2011. године 
Стање у Србији по попису из 2011. године је следеће: Приштина и Крагујевац губе ранг првог града, тако да преко 150.001 становника имају само Нови Сад, Ниш и Београд. У другом рангу су само Приштина и Крагујевац, јер Суботица има смањен број становника у односу на претходни попис. Суботица, Зрењанин, Шабац, Панчево, Смедерево, Ваљево, Ужице, Чачак, Краљево, Крушевац, Нови Пазар, Врање и Лесковац су у трећем рангу, односно имају преко 50 хиљада становника. Мање од наведеног броја имају Сомбор, Кикинда, Вршац, Сремска Митровица, Пожаревац, Зајечар и Пирот. Лозница остаје град са најмањим бројем становника кроз цео посматрани период (Прилог 5).

\section{ЗАКЉУЧАК}

Градови су на простору данашње државе Србије присутни од римског периода. Временом, значај одређених градова се мењао у складу са историјским, политичким и друштвеним променама, те се на тај начин мењала и њихова хијерархија.

Према правилу реда величине Нови Сад као други град у хијерархији има три пута мање становника него што би требало, и то представља највеће одступање. Слична ситуација се јавља и у осталим градовима, где према очекиваном реду величине градови у Србији имају знатно мање становника. Од 26 анализираних градова, Вршац има најмању разлику између очекиваног и стварног броја становника у односу на ранг у хијерархији.

Урбана примарност је током анализираних пописа константно била већа од 6, што наглашава разлику између Београда и осталих градова у Србији.

Према Шмуковој методи за одређивње централитета насеља највеће позитивне вредности активног становништва запосленог у терцијарном и квартарном сектору имају највећи градови (Нови Сад, Београд, Ниш). Најниже негативне вредости имали су Врање, Шабац и Крушевац.

У градове који имају по последњем попису преко 150.000 станивника спадају Нови Сад, Београд и Ниш, што је мање него 2002. године, када су у ову категорију спадали и Крагујевац и Приштина.

\section{ЛИТЕРАТУРА И ИЗВОРИ}

Jefferson, M. (1939) 'The law of the primate city', Geographical Review, 29(2), 226-232. Nicholson, J. P. (2003) 'Why Do So Many Developing Countries Have Primate Cities?' In: Urbanization in the Context of Development, Middlebury College 2003 Conference. Murray, M. (2003) 'On Urban Primacy', In: Urbanization in the Context of Development, Middlebury College 2003 Conference.

Mutlu, S. (1989) 'Urban Concentration and Primacy Revisited: An Analysis and Some Policy Conclusions'. In: Economic Development and Cultural Change, Vol. 37, No. 3 April 1989, pp. 611-613. 
Berry, B. J. L; Garrison, W. L. (1959): "Alternate Explanations of Rank-size Relations", In: Mayer, H. M.; Kohn, C. F. (eds.), Readings in Urban Geography. The University of Chicago Press,Chicago pp. 230-239

Soo, T. K. (2002): "Zipf's Law of Cities: A Cross Country Investigation", Regional Science and Urban Economics Volume 35, Issue 3, May 2005, Pages 239-263

Sarkar, S. and Maji, S. (2013), An Analysis of Urban Primacy: The Case of Kolkata, Indian Journal of Applied Research, 3(3), 158-162.

Yousuf, T., Shah, S. A. (2014). An analysis of urban primacy in Himalayan settlements: the case of Srinagar City of Jammu \& Kashmir, International Journal of Recent Scientific Research Vol. 5, Issue, 9, pp.1670-1674,

Бубало-Живковић, М. (2016). Урбани развој Србије, Природно-математички факултет, Департман за географију, туризам и хотелијерство, Нови Сад http:// www.dgt.uns.ac.rs/download/urbrazvojl.pdf

Ћурчић, С. (1992). Географија насеља, Природно-математички факултет, Институт за географију, Нови Сад.

Vujnić, A. (2014). Regional development indicators, case study- Serbia, Researches Reviews of the Department of Geography, Tourism and Hotel Management, 43 -1, pp. 28-41.

Аничић, Ј., Лакета, М., Вукотић, С. (2011). Инвестищиона политика и регионални развој Србије у транзиционом периоду, Београд.

Schmook, G. (1968). Wiskundig afgebakene ommelanden en hinetrlanden van de Belgische steden op de basis van geselektioneerde diensten uit de tertiare sektor, Geografische Tijdschrift.

Rochefort, M. 1957: Méthodes d'étude des réseaux urbains: intérêt de l'analyse du secteur tertiaire de la population active. Annales de géographie 66-354. 